\title{
New combinations in Australasian Zostera (Zosteraceae)
}

\author{
Surrey W.L. Jacobs ${ }^{1}$, Donald H. Les ${ }^{2}$ and Michael L. Moody ${ }^{3}$
}

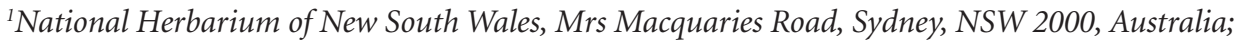
Author for correspondence: surrey.jacobs@rbgsyd.nsw.gov.au

${ }^{2}$ Department of Ecology and Evolutionary Biology, University of Connecticut, Storrs, Connecticut 06269-3043, USA

${ }^{3}$ Indiana University, Department of Biology, Jordan Hall 142, 1001 E. 3rd St., Bloomington, Indiana 47405, USA

\begin{abstract}
The new combinations Zostera muelleri subsp. capricorni (Ascherson) S.W.L.Jacobs, Z. muelleri subsp. mucronata (Hartog) S.W.L.Jacobs and Z. muelleri subsp. novazelandica (Setchell) S.W.L.Jacobs are provided for species recently recommended to be treated as a single species.
\end{abstract}

\section{Introduction}

Les et al. (2002) provided ITS, $\operatorname{trnK}$ and $r b c L$ sequences of numerous samples of the family Zosteraceae, concentrating on the Australasian taxa. These were supported by a cladogram derived from morphological data. All results indicated that:

(i) there was no support for retaining Heterozostera as a distinct genus unless subgenus Zosterella (which contains all of the other Australasian Zostera taxa) was raised to genus level (Tomlinson \& Pozluszny 2001); and

(ii) there was no support for maintaining the species Zostera capricorni, Z. muelleri, $Z$. mucronata and $Z$. novazelandica and that these could not be reliably and consistently distinguished from each other. The recommendation was that they be treated as one species, Z. capricorni (though Z. muelleri has priority and is the name that should have been recommended).

Neither conclusion is novel (Phillips \& Meñez 1988). Les et al. (2002) present the most detailed analysis of characters and the most recent review. The results provide no support for the solution suggested by Tomlinson \& Pozluszny (2001) and suggest some sorting of specimens on a geographical basis. While some of these loose groups have morphological markers, they do not all have useful markers. Those markers that are discernible are not completely reliable and there is some breakdown between them, especially where two groups overlap. Nonetheless experienced practitioners can and do make distinctions most of the time, except for the indicated molecular differences within Z. muelleri s. str. In response to those results (Les et al. 2002) and to reduce 
the probability of losing valuable field information, we here recognise the four taxa as subspecies of $Z$. muelleri, the earliest available name for the group. Subspecies is an appropriate level of recognition as the taxa are sorted geographically and there is a considerable (?uncomfortable) degree of character overlap between them.

Zostera muelleri Irmisch ex Asch., Linnaea 35: 168 (1867)

Type (fide Hartog 1970:90): "Melbourne, at the mouth of the river Yarra, "Australia Felix", fl., November 1852, F. von Mueller (Type, MEL, P)”.

\section{Zostera muelleri subsp. muelleri}

Zostera muelleri subsp. capricorni (Asch.) S.W.L.Jacobs, comb. et stat. nov.

Basionym: Zostera capricorni Ascherson, Sitzungsber. Ges. Naturf. Freunde Berlin: 11 (1876)

Type (fide Hartog 1970:85): “Moreton Bay, 10-10-1875, Naumann (Type, UC)”.

Zostera muelleri subsp. mucronata (Hartog) S.W.L.Jacobs, comb. et stat. nov.

Basionym: Zostera mucronata Hartog, Verh. Kon. Ned. Akad. Wetensch., Afd. Natuurk. Tweede Reeks 59 (1): 91-92 (1970)

Type citation: "Mandurah [W.A., small bay near the bridge], in sandy estuary, 16-81950, G.G. Smith 274" (holo L; iso PERTH-U!).

Zostera muelleri subsp. novazelandica (Setch.) S.W.L.Jacobs comb. et stat. nov.

Basionym: Zostera novazelandica Setchell (1933: 816).

Type citation: "Bluff, [lower littoral zone,] N.Z., W.A. Setchell, Mar 111927 Herb U Calf 313091" (holo UC).

A discussion of lectotypes is currently in press with Flora of Australia (John Kuo pers. comm.).

\section{References}

Hartog, C den (1970) The sea-grasses of the World. Verhandelingen der Koninklijke Nederlandse Akademie van Wetenschappen, afdeeling Natuurkunde Tweede Reeks 59, no. 1.

Les DH, Moody ML, Jacobs SWL \& Bayer RJ (2002) Systematics of seagrasses (Zosteraceae) in Australia and New Zealand. Systematic Botany 27: 468-484.

Phillips RC \& Meñez EG (1988) Seagrasses. Smithsonian Contributions to the Marine Sciences no. 34 .

Setchell WA (1933) A preliminary survey of the species of Zostera. Proceedings of the National Academy of Sciences Washington 19: 810-817.

Tomlinson PB \& Pozluszny U (2001) Generic limits in the seagrass family Zosteraceae. Taxon 50: 429-437.

Submitted 20 September 2005, accepted 06 December 2005 